\title{
Surpassing the Ekphrastic Experience in Modernist Poetry
}

\author{
Bhagyalekshmi R
}

\author{
MA in English Literature, EFL University, Hyderabad, India
}

\begin{abstract}
The modernist poetry developed a fear of words being taken in their true literal sense, which W.T.J. Mitchell called the "Ekphrastic Fear". This paper explores how the fear of literalism results in selfreflexivity, semiotic transparency and the pursuit of openness in Modernist poems. Ekphrasis verbally describes a work of art or an event that is either real or is imagined. The root meaning of Ekphrasis comes from the Greek words "ek" that means 'out' and "phrásis" that means 'speak', and "Ekphrazien" means 'speaking out' or 'telling in full'. In the process, the poet gives voice to a silent object, and by detailing its fixed form, becomes immortal and static, thus suspending time. Ekphrasis is considered thrice removed from reality, being a representation of the original's representation. Thus, a poet records his visual experience, whether it is what he has seen, reconstructed or imagined, as he perceives them, within the visual space that he constructs. In such poems, the image is the subject and the meaning is determined by the verbal representation of the subject. The tradition of Ekphrastic poetry as a literary work began with Homer's description of the shield of Achilles in his book Illiad, and there are many poems that proliferated ever since.
\end{abstract}

.Keywords- Ekphrasis, Experiments, Innovations, Openness, Reinforced-Individualism, Self-reflexivity.

\section{INTRODUCTION}

The uniqueness of ekphrasis in Modernist period stems from the Modernist rebellion against the traditional norms and methods that existed in art, literature, architecture, philosophy and music. With the rejection came the wave of experimentation and individualism, both of which were anathema in the past. This dissatisfaction largely emerged out of the horrors that the world saw in the aftermath of the World War, rapid urbanization, industrialization, and the coming of the mass culture. The result was the inwardness, selfconsciousness, alienation, and fragmentation in the modern society which strongly reflected in art, especially in poetry. Andrew Marvell's "the Picture of Little T.C. in a Prospect of Flowers", John Keats's "Ode on a Grecian Urn", Robert Browning's "My Last Duchess" and P.B. Shelley's "On the Medusa of Leonardo Da Vinci in the Florentine Gallery" are some of the finest Ekphrastic poems that have come out. Brueghel's famous painting of Icarus became the subject of not less than eighteen poems, two of which were W.H. Auden's "Musee des Beaux Arts" and William Carlos William's "Landscape with the Fall of Icarus". Brueghel's "Hunters" also was verbally represented by Williams, John Berryman, Norbert Krapf, and John Langland. The arts have influenced each other all through the ages in their simultaneous growth and development. The revolutions in Modernist poetry were strongly stimulated by the changes in the visual artistic scene. Inspired by the "Manet and the Post-Impressionists" of 1910,the modern French painters who chose to move away from naturalism, the Armory Show or International Exhibition of Modern Art was held at the $69^{\text {th }}$ Regiment Armory in New York in the year 1913. While the Armory Show was an exhibition with fresh, new and original works of art that caused a surge of heated controversy, the painters in New York, on the other hand, found in it the opportunity to create an atmosphere of artistic daring. The show made people realize that the perception of things and their relation with one another, distinguished the Modern age from the past. Thus there evolved a new way of viewing external objects and a new way of imagination while representing them. Cubism, Futurism and other revolutionary art forms, along with postimpressionism, were featured in the exhibition that turned out to be one of shock and amusement for the Americans in New York, Chicago and Boston. The impact was not restricted to painters alone, as it spread to other fields of art as well. This revolution in painting made the poets aware of the lack of good innovative work in the poetry of that time. The mutual lack of respect for the basic laws of pictorial art and their common sense of individuality was the common thread that ran through the style of the Armory Show painters. This made the poets dissatisfied with their literary laws and traditions and engaged in iconoclasm. The new, shocking and the strange ways of Modernism and their need to "make it new", emerged out of the abandoning of the artistic values that were considered sacred from 
the Renaissance onwards. The slogan "Make it new" is widely attributed to Ezra Pound. He Pound disagreed with the notion of rejecting everything that belonged to the past, which the Futurists and Dadaists believed in. On the other hand, he incorporated the ancient traditions and forms into his works.

\section{TRADITION AND TRANSGRESSION}

Marcel Duchamp, one of the artists who were featured in the show, with his different attitude towards art paved way for the poets to reject the traditional notions of art and culture. Along with Picasso and Matisse, he revolutionized the developments in the art in the beginning of the twentieth century. He rejected the "retinal" art works, which he believed were just pleasing to the eyes and didn't contribute in any way towards the evolution of art or human. It was during this time that Dada or Dadaism, an art movement that is called anti-art movement, emerged. With this idea, Duchamp turned ordinary things like a bicycle wheel, urinal, bottle rack, shovel, into works of art, which came across as an attack on the conventional notions of the subject matter of art and the representation of the artist's personal vision of reality. By making art out of these ordinary objects, he created a sense of amusement in the spectators that they weren't used to. Thus he established that any object could be considered as art.

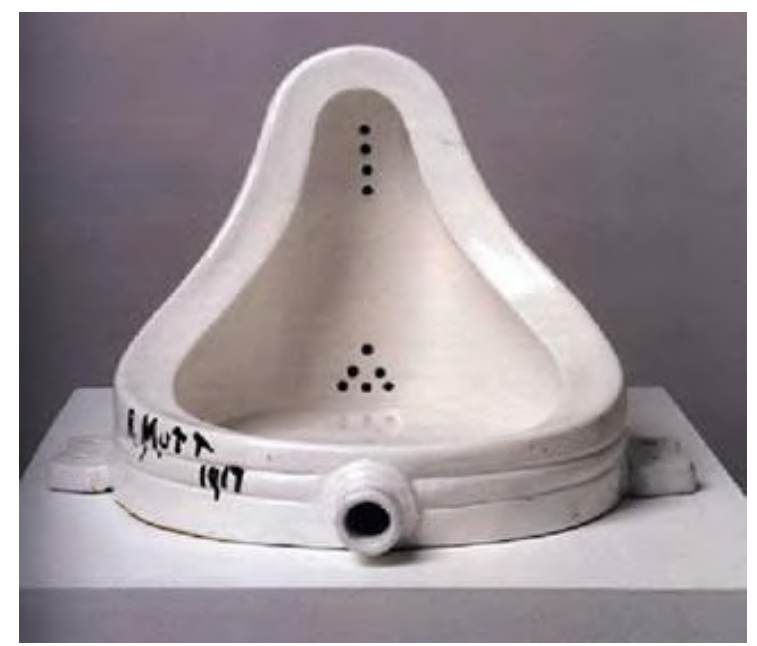

Fig.1: The Fountain- a urinal that is kept inverted was signed and exhibited as a piece of art by Duchamp.

Duchamp influenced the art of the twentieth century in the ways of perceiving an object of use into an object of beauty. He chose items, and by making small changes in their positioning, those items were declared works of art.

Innovations in visual art found its way into the Modernist poetry with new experiments in form and style, new modes of expression and complex nature of their themes and meanings. With individualism getting lost in the crowd, it became necessary for the artists to make people think about their existence through their works. Wallace Stevens, William Carlos Williams and Gertrude Stein were among them who acted towards this idea in reinforcing the need for individualism. Thus Modernism became a period of self-consciousness and inward looking attitude, with each and every object being given their share of uniqueness and importance. Ekphrasis was widely employed by the Modernist poets as a gateway for their desire to paint in words what they perceive and imagine. W.J.T. Mitchell in his article, "Ekphrasis and the Other" divides Ekphrasis into three phases of realization - Ekphrastic difference, Ekphrastic hope and Ekphrastic fear.

The first might be called "ekphrastic indifference," and it grows out of a commonsense perception that ekphrasis is impossible. This impossibility is articulated in all sorts of familiar assumptions about the inherent, essential properties of the various media and their proper or appropriate modes of perception. . . This literature reflects a second phase of fascination with the topic I will call "ekphrastic hope." This is the phase when the impossibility of ekphrasis is overcome in imagination or metaphor, when we discover a "sense" in which language can do what so many writers have wanted it to do: "to make us see.". - But the "still moment" of ekphrastic hope quickly encounters a third phase, which we might call "ekphrastic fear." This is the moment of resistance or counter desire that occurs when we sense that the difference between the verbal and visual representation might collapse and the figurative, imaginary desire of ekphrasis might be realized literally and actually. (W.T.J. Mitchell, "Ekphrasis and the Other")

In the process of verbalizing a visual image, multiple layers of meanings and perceptions are added to the writing and thus, the language tends to be taken more critically than its less complex visual equivalent. Even though Ekphrastic poems are about things, they are written as an attempt by the poets to enable the readers to see beyond the words. Consequently, the various dimensions of the poems point to the text itself, declaring on its own for what it is. The fear of the literalism arising from the likelihood of the verbal given more prominence than the actual visual image prompted the Modernist poets to write self-reflexive poems. They make the readers aware that the work of art that they are trying to visualize is, in fact, nothing more than a poem.

The self-reflexivity of the Modernist texts pose as opaque surface, urging the readers to understand it, in its terms of poetic forms and techniques. For instance, 
William Carlos Williams's "Red Wheelbarrow" is meant to be taken as a poem that is complete on its own with a single sentence:

so much depends
upon a red wheel
barrow
glazed with rain
water
beside the white
chickens (Williams 224)

The poem forces the reader to take notice of the line breakages and fragmentation. The first line "so much depends" makes it evident that the poem is aware of itself. An ordinary sentence is made into a poem with careful breaking down into short lines, and as a result, stressing importance on each element. While describing what seems to be the scene of a moment, the poet wants us not to forget the fact that it is a poem that we are reading. Moreover, by describing the positioning of each and every object, the poem points out at the image that it conveys.

Self-reflexivity can be clearly seen in Williams" "The Great Figure":

Among the rain
and lights
I saw the figure 5
in gold
on a red
fire truck
moving
tense
unheeded
to gong clangs
siren howls
and wheels rumbling
through the dark city. (Williams 230)

Here, it is not merely the description of a sign that is seen on a fast-moving truck, but it is described as seen by the speaker. "I saw the figure 5 " on the third line puts the poem into its place.

In relation to Williams's approach to the literary commentary of Brueghel's pictures, Steiner affirms that "Williams's understanding of the ut pictura poesis simile went beyond the metaphoric... to the creation of structural equivalents of paintings in his poems" (1982: 73). What we find in "Portrait of a Lady" does not actually constitute a "structural equivalent" of a picture, but it offers ample scope for discussion of the limitations of language used for Ekphrastic purposes. Furthermore, it leads Williams towards a path which he followed from then on in relation to his Brueghel series. (Carbajosa 55)

Modernist poems, with explicit descriptions, can make themselves look opaque-surfaced. Most of the poems written by Gertrude Stein are based on 'objects', 'rooms' and 'food'. While the poems that are supposed to be mere descriptions of objects create an illusion to be taken for its surface image, the language proves otherwise. There were a lot of themes that were dealt with by the poets. The horrors of the war, along with rapid urbanization created complete disorder and chaos in the world. Mass production resulted in the fall of handmade and handicraft industries, which quickly led to the loss of individuality. Chaos of the modern age also made it necessary to find beauty in the chaotic mundane things. Regard for broken pieces came to be a common trait among Modernist paintings and Modernist literature. With more machinery, laborers started to be seen as mere commodities and not as human beings. People were made to work in poor working conditions and were exploited to the maximum. As machines were given more importance than humans, artists, especially poets expressed their disappointment at the gravity of the situation. This meant that poems could no longer be seen as a source of pleasure, but their symbolic representation should also be accounted for. Consequently, attempts started to be made to read through the seemingly opaque surface to understand what it means, hinting at its semiotic trans parency.

Williams wrote about things as they are in most of his poems, the things ranging from a sign he sees on a truck to that of a painting made by Pieter Brueghel. The collection "Pictures from Brueghel" contains poems written on various paintings by the painter. In the poem "Landscape with the Fall of Icarus" with the tragic death of Icarus, as painted by Brueghel, Williams engages in a detailed description of each and every element of the painting. He begins the poem by taking the name of the painter:

$$
\begin{aligned}
& \text { According to Brueghel } \\
& \text { when Icarus fell } \\
& \text { it was spring (Williams 4) }
\end{aligned}
$$

This acknowledgment can be seen in his other poems also. By mentioning the name of the artist in every poem that are written about paintings, he asserts the authority of the artist and the fact that the piece is a poem about a painting. More than being a poem about a painting, it talks about the poet's view points and perceptions. 


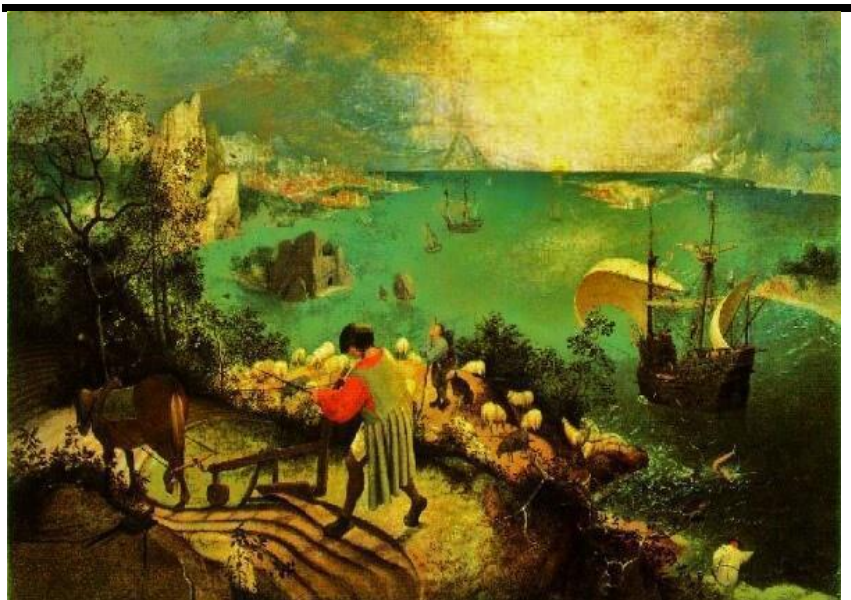

Fig.2: "Landscape with the Fall of Icarus" by Pieter Brueghel. Note that the legs of the drowning Icarus are barely visible, while the landscape with the farmer catches our attention quickly. The same technique is followed by Williams in his poem too.

It was Brueghel's choice to give primary importance to the farmer and other people and things on the landscape, rather than focusing on Icarus, who is drowning barely noticed in the lake. Thus he presents what he thinks the artist wants to convey through the painting. Every part of the landscape is described in detail and thus it becomes self-revealing. The eyes of the viewer automatically go to the prominent features, than at the subject of the painting. The same technique is followed by Williams who takes the readers by lead from one element to another. The details are presenting in the order of their visual importance or how the viewer registers them. The drowning of Icarus is not mentioned till the last line, the way it wouldn't catch the notice of the viewer of the painting, till the end. Icarus, the hero of the myth is given secondary importance, while the ordinary people and animals are given much prominence.

The lack of punctuations also gives the description a sense of happening in a flow. Moreover, the short lines enable in giving prominence to each and every mentioned detail of the scene. The same method is followed by him in "Hunters in the Snow", which is also from "Pictures from Brueghel". A scene with the harsh weather is made static in the painting, which was taken by the poets to describe in his style. The last lines of the poem show Williams' awareness of the artistic world:

\author{
Brueghel is the painter \\ concerned with it all has chosen \\ a winter- struck bush for his foreground to \\ complete the picture. (Williams5)
}

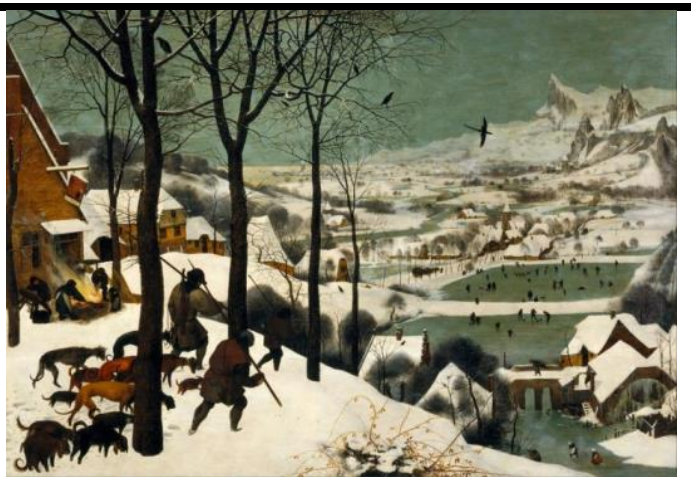

Fig .3: The Hunters in the Snow by Pieter Brueghel

Here again, it was the poet who chose to detail the foreground at the end and chose to focus on the background of the picture till then. As the poet makes a declaration about what follows is important and should be taken seriously, the ordinary mundane objects become things of high relevance. Moreover in Williams' works, there is scope for the readers to make interpretations and this space is left by the poet intentionally. For instance, the objects mentioned in "The Red Wheelbarrow" are familiar - "wheel," "water," "chicken". They are made specific with "red," "rain," "glazed" - which makes these ordinary objects, when linked together, make a whole new meaning.

Gertrude Stein, in her poems that are seemingly difficult to comprehend, wrote on a variety of themes under the banner of 'objects', 'room' and 'food'. The fact that she chose to wrote about a box, coffee, an umbrella, a red stamp, a plate and so on proves how she gels in with the Modernist philosophy. There is nothing extra-ordinary about these everyday objects. They are all used by ordinary people in their daily life, which tend to be taken for granted. Her choice of works was based on their intended quality and not for their accepted meaning. In her collection of poems Tender Buttons, she wrote about very ordinary objects like a carafe, cushion, a box and so on. In "A Carafe, That is a Blind Glass", he describes carafe in terms that detach it from the concept that we know about.

A kind in glass and a cousin, a spectacle and nothing strange a single hurt color and an arrangement in a systemto pointing. (Stein 3)

Here, a familiar object is de-familiarized with its imaginative and creative description. The "nothing strange" (3) is ironic because making the object strange seems to be the aim of the poet. Stein was aware of the alienation and disorder that existed around her and didn't want to be a part of the convention

All this and not ordinary, not unordered in not resembling. (3)

Thus, by talking about objects that aren't usually discussed in poems, she very well belonged to an era of 
artistic revolution. Stein's poems are considered difficult to understand and interpret. This is because of the various possible interpretations that could be derived from these lines.

The blue coat that she talks about in her"A Blue Coat" can contain any number of inherent symbols:

A blue coat is guided guided away, guided and guided away, that is the particular color that is used for that length and not any width not even more than a shadow. (9)

The "blue coat" can stand for anything from life to shadows that are "guided guided away, guided and guided away". With the deceptive covering of opacity, the poem is an example of Modernist poem both being self-reflexive and semiotically transparent.

The Modernists did not believe in presenting a fixed meaning for their poetic creation. Instead, they left enough space for the readers to draw their own interpretations and conclusions. Ekphrastic fear has helped in reducing the power the poets have on the readers. He or she draws her own image from what can be understood of the poem.

In "The red wheelbarrow", though Williams has mentioned the particularity of the positioning of every object, the reader has the scope to imagine the scene. The objects and components are perfect in themselves. Though they exist independently, they are linked together by the thread of imagination. The sense of openness in the approach can be seen in Stein's poems also. The objects that she describes are not precise like her carafe, stamp, piano, hair, etc. Since the poets had aimed at individuality and creating an alienation effect, the central images of their poems had a uniqueness of their own. This meant that the scope for imagination was limited, in spite of the poets' desire for openness.

Marianne Moore wrote “The Magician's Retreat" after she saw Rene Magritte's "Empire of Light" in the New York Times Magazine. The poet describes the house in great detail, claiming that she has "seen it".

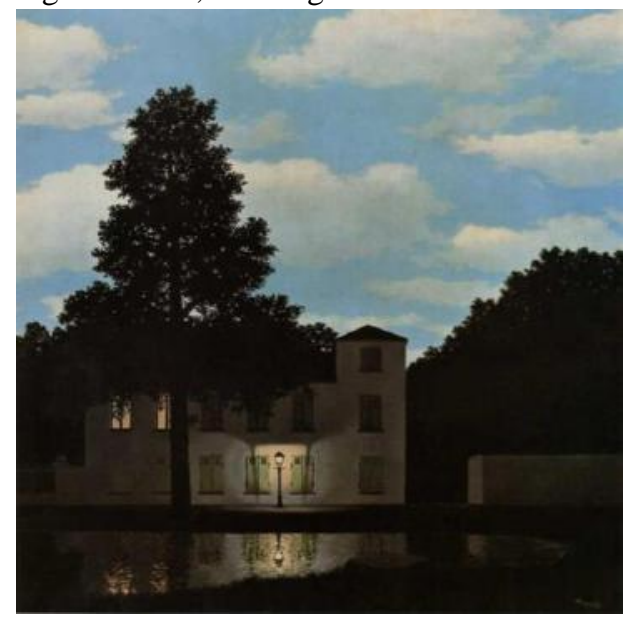

Fig.4: Rene Magritte's "Empire of Light" of moderate height,

(I have seen it)

cloudy but bright inside

like a moonstone,

while a yellow glow

from a shutter-crack shone,

and a blue glow from the lamppost

close to the front door.

It left nothing of which to complain,

nothing more to obtain,

consummately plain. (Moore 360)

There is the juxtapositions of darkness and light, when she used "cloudy" and "bright", "yellow glow' and "blue glow', that give a haunted outlook to the house that is set in a bright environment. When she says that there is "nothing of which to complain", she admits how plain the house looks for an onlooker, yet there is nothing more to ask for. The house here could also signify human relationships that put a constraint to our expectations by not having anything to demand or accept. Even the black tree at the back is clearly pictured and given certain "definiteness" that again puts a limit to our imagination and expectations. There is a certain kind of discreetness surrounding the painting, which can be seen in Moore's poem too. By describing the exact colour and position of objects, she limits the imagination of the reader.

Alongside Williams and Moore, Wallace Stevens also acknowledged the importance of modern art as a fundamental influence in his poetry. The typical example of ekphrastic poetry by Stevens is "Anecdote of a Jar". Unlike the ornamental decorative "urn", Stevens' "jar is more earthly and realistic. It is given the status of just another commodity, while also maintaining simplicity in the language of the poem. The act of placing the round jar (a man-made object) on the wilderness (nature) naturally points out to the claiming of the environment and everything that's in it by man. The process of "rising up of the wilderness" and "sprawling around the wild" shows how the interference of man collides with the natural functioning of nature. The repeated use of the word "round" gives a sound of roundness to the poem. The placing of the jar on the hill is also symbolic of God's creation of man in the already designed world. Like how it is the jar that makes changes to the wilderness, man exploits the nature according to his own whims and wishes.

\section{CONCLUSION}

The Ekphrastic fear encompasses the possibility of the worth of the actual thing being undermined while considering its literature, which is thrice removed from reality. In the process, multiple layers of meanings and 
perceptions are added to writing that is meant to be an equivalent representation of the visual image. The different dimensions point to the text itself, declaring on its own for what it is. The self-reflexivity of the Modernist texts pose as opaque surface, urging the readers to understand it, in its terms of poetic forms and techniques. As already seen, William Carlos Williams's "Red wheel barrow" is meant to be taken as a poem that is complete on its own with a single sentence. It forces the reader to take notice of the line breakages and fragmentation. The horrors of the war, along with the rapid urbanization had its impact on the people losing their individuality, alienation and complete disorder and chaos in the world. This reflected in the Modernist literature to a great extent, especially in poetry. While the poems create an illusion to be taken for its surface image, the language proves otherwise. The methods of writing underwent changes with their disregard for the traditional forms. For example, Gertrude Stein's poems are often considered difficult to comprehend with its deceptive simplicity. A poem about the "Red Stamp" doesn't seem to be about it with its descriptions. Consequently, attempts are made to read through the seemingly opaque surface to understand what it means, hinting at its semiotic transparency. The Modernist poems delude the readers to believe that they are open to interpretations. The apparition of the possibility of having different facets to the poem is interrupted by the fact that the scope is limited. The carafe of Gertrude Stein appears in different images, but ultimately, it cannot be anything but what the poet has created.

\section{REFERENCES}

[1] Abrams, M. H, \& Harpham, G. (2011). A glossary of literary terms. Cengage Learning.

[2] Bloom, H. (1980). Wallace Stevens: The poems of our climate. Cornell University Press.

[3] Carbajosa, N. (2012). Ekphrasis and Modernism: A Study of Two Poems by Wallace Stevens and William Carlos Williams.

[4] Camfield, W. A. (1990). Marcel Duchamp's fountain: Its history and aesthetics in the context of 1917. Marcel Duchamp: Artist of the century.

[5] Dijkstra, B. (1978). Cubism, Stieglitz, and the Early Poetry of William Carlos Williams: The Hieroglyphics of a New Speech (No. 37). Princeton University Press.

[6] Gelpi, A. (2006). Poetic Language and Language Poetry: Levertov, Duncan, Creeley. Gelpi and Bertholf, 180-98.

[7] Halter, P. (1994). The revolution in the visual arts and the poetry of William Carlos Williams (Vol. 76). Cambridge University Press.
[8] Heffernan, J. A. (2004). Museum of words: The poetics of ekphrasis from Homer to Ashbery. University of Chicago Press.

[9] Middleton, T. (Ed.). (2003). Modernism: Critical Concepts in Literary and Cultural Studies (Vol. 5). SUNY Press.

[10] Mitchell, W. J. J. T. (1994). Ekphrasis and the other: Picture theory.

[11] Stein, G. (2017). Tender buttons: objects, food, rooms. Broadview Press.

[12] Steiner, W. (1988). Pictures of romance: form against context in painting and literature. University of Chicago Press.

[13] Stevens, W. (2011). The collected poems of Wallace Stevens. Vintage. 